\title{
Vitamin D content analysis of agricultural products and processed foods
}

\author{
Jong-Soon $\mathrm{Lim}^{1}$, Hyun-Jeong Kim ${ }^{1}$, Sang-Hoon Lee ${ }^{3}$, Sam-Pin Lee ${ }^{1,2 *}$ \\ ${ }^{1}$ The center for traditional microorganism resources, keimyung university, Daegu 42601, Korea \\ ${ }^{2}$ Department of food science and technology, keimyung university, Daegu 42601, Korea \\ ${ }^{3}$ Food \& nutrition division, department agrofood resources, national institute of agricultural science, \\ rural development administration (RDA), Wanju 54875, Korea
}

\section{농식품자원 및 가공식품에 대한 비타민 D 함량 분석}

\author{
임종순 ${ }^{1} \cdot$ 김현정 $^{1} \cdot$ 이상훈 $^{3} \cdot$ 이삼빈 $1,2 *$ \\ ${ }^{1}$ 계명대학교 전통미생물자원개발 및 산업화연구센터, ${ }^{2}$ 계명대학교 식품가공학과, \\ 3농촌진흥청 국립농업과학원 농식품자원과 식생활영양과
}

\begin{abstract}
This study was performed to update the National Standard Food Composition Table (NSFCT), published by the Korean Rural Development Administration, especially focusing on vitamin D content in Korean agricultural products and processed foods. A total of $\mathbf{9 6}$ kinds of agricultural products and processed foods were analyzed for vitamin D content by using liquid chromatography - mass spectrometry (LC-MS/MS). The recovery rates of the standard materials SRM 1849a (Infant/Adult Nutritional formula) and BCR-122 (Margarine) were $108.18 \%$ and $96.15 \%$, respectively. All analyses results were below the control line based on the quality control chart for vitamin $D$. Vitamin D was detected only in 25 out of the 96 products and foods that were analyzed. The vitamin D content in cereals, potato, nuts, and seeds ranged from 0 to $4.11 \mu \mathrm{g} / 100 \mathrm{~g}$. In sugars and sweeteners, pulses, oils, teas, and processed foods, the vitamin D content ranged from 0 to $6.13 \mu \mathrm{g} / 100 \mathrm{~g}$, whereas in vegetables and mushrooms, it ranged from 0 to $644.72 \mu \mathrm{g} / 100 \mathrm{~g}$. The highest vitamin $D$ content was found to be $644.72 \mathrm{\mu g} / 100 \mathrm{~g}$ in naturally dried oyster mushroom.
\end{abstract}

Key words : vitamin D, agricultural products, processed foods, LC-MS/MS

\section{서 론}

비타민 D는 화학적 구조가 다른 5가지 형태(D1-D5)가 있지만 보편적으로 비타민 D2(ergocalciferol)와 비타민 D3(cholecalciferol)로 존재하는 것으로 알려져 있다(1). 비 타민 D2는 주로 식물에 의해서 합성되고 인체에서는 합성 되지 않으며, 비타민 D3는 자외선 B에 노출되었을 때 피부 에서 합성된다(2). 체내에서 비타민 $\mathrm{D}$ 는 비타민 D 결합단백

*Corresponding author. E-mail : splee@kmu.ac.kr Phone : 82-53-580-5554, Fax : 82-53-580-6465

Received 11 November 2019; Revised 11 December 2019; Accepted 12 December 2019.

Copyright (c) The Korean Society of Food Preservation. All rights reserved.
질과 결합하여 간으로 이동되고, 수산화되어 25-hydroxyvitamin 으로 된다. $25-H y d r o x y$ vitamin $\mathrm{D}[25(\mathrm{OH}) \mathrm{D}]$ 는 체내의 비타 민 D 상태를 가장 잘 반영하는 표지자이며, 신장에서 활성 형인 1a, 25-dihydroxyvitamin $\mathrm{D}[1 \mathrm{a}, 25(\mathrm{OH}) 2 \mathrm{D}]$ 로 된다(3)

비타민 $\mathrm{D}$ 는 인체내 칼슘 항상성을 조절하는 호르몬의 역할 뿐만 아니라 면역조절, 세포증식, 분화, 괴사, 혈관 신생을 조절하는 기능을 가지고 있으며(4,5), 비타민 D 결핍 시 심혈관계 질환, 당뇨병, 일부 암 등의 만성질환의 발병 위험이 증가하는 것으로 보고되어 비타민 $\mathrm{D}$ 에 대한 관심이 증대되고 있다(6). 비타민 $\mathrm{D}$ 의 섭취로 대퇴골 골절과 비척 추골 골절의 위험을 낮춰주며(7), 근육기능의 향상과 반사 신경 보호 강화(8,9), 혈압상승 완화(10), 염증과 혈전생성 억제(11) 등의 여러 연구결과들이 보고되고 있다.

그러나 비타민 $\mathrm{D}$ 의 중요성에도 불구하고 National Health 
and Nutrition Examination Survey자료에 따르면 미국 성인 의 $23 \%$ 만이 적정수준의 $25(\mathrm{OH}) \mathrm{D}$ 농도가 유지하는 것으로 나타났다(12). 현대인들의 생활양식의 변화로 실외활동량 이 적어져 자외선 노출 시간이 감소되고, 스모그, 안개 등의 환경요인에 의하여 비타민 D 피부 합성량이 감소하고 있다 (13-15). 우리나라의 경우에도 골다공증을 동반한 폐경여 성을 대상으로 조사한 결과 적정수준인 $30 \mathrm{ng} / \mathrm{mL}$ 에 도달하 지 못하는 비율이 $92 \%$ 나 되는 것으로 보고되었다(16). 지금 까지 식품의 섭취로 체내 비타민 D 농도를 증가시킬 수 있으나, 비타민 D 급원식품으로는 연어, 참치, 고등어와 같은 기름기 많은 생선을 포함하여 쇠고기, 달걀, 버섯, 우유 및 유제품, 동물의 간 등 매우 제한적이다.

최근, 국내 식품 영양성분 데이터의 활용도가 증가하고 있으나, 영양소의 종류별, 분석된 식품 종류별 정보 및 식품 성분 분석과정과 결과에 대한 상세 정보가 많이 부족한 실정이다. 미국 농무성(USDA)에서는 미국 내에서 소비되 고 있는 식품의 영양성분 함량에 관한 데이터베이스를 제시 하고 있고, 일본에서는 시중 유통 자료인 관련 학계 혹은 과학기술청 보고서 자료 등을 이용하여 실수요자 중심의 자료를 발간하고 있다. 우리나라의 식품의 영양성분 정보 구축의 경우에 농촌진흥청에서 1970년 초판의 발간 후 5년 주기로 개정판이 발간되고 있으며, 현재 제9개정 국가표준 식품성분표까지 발간되었다(17).

비타민 $\mathrm{D}$ 는 인체 내 중요한 역할과 기능을 수행하는 필수 영양소로 질환과 관련된 연구가 대부분으로, 다양한 가공 식품을 포함한 식품 원료에 대한 비타민 D 함량 연구는 매우 제한적이다. 따라서 본 연구에서는 국내에서 상용되 는 식품 중 우리나라에서 소비가 가장 많은 다소비 식품을 선별하여 식품에 함유되어 있는 비타민 D 함량 분석을 실시 하여 국가표준식품성분표 개정을 위한 $\mathrm{DB}$ 구축 및 국민영 양평가의 기초자료로 제공하고자 하였다.

\section{재료 및 방법}

\section{재 료}

본 연구에서 비타민 D 추출을 위해 사용된 피로가롤 시약 은 Sigma사(St. Louis, MO, USA)로부터 구입하였고, 에탄 올, 메탄올 및 $\mathrm{n}$-헥산은 Honeywell(Morris plains, NJ, USA) 로부터 구입하여 사용하였다. 표준품인 비타민 D2와 비타 민 D3는 Sigma사의 순도 $98 \%$ 이상의 HPLC급을 구입하여 사용하였으며, 그 외 실험에 사용된 시약은 특급 이상을 사용하였다.

\section{시료의 선정 및 전처리}

본 연구에서 사용된 시료는 국민건강영양조사를 통해 생산되는 국민건강통계를 참고로 하여 국내 다소비, 다빈
도 이용식품과 통계청의 농림어업 총 조사 등을 활용하여 선정한 농식품자원 및 가공식품을 선별하였고, 이렇게 선 정된 시료들은 2018년 농촌진흥청이 국가표준 식품성분표 제 10 개정판을 발간하기 위한 연구사업의 일환으로 선정되 었다.

곡류 및 관련제품(8종), 감자 및 전분류(1종), 당류(5종), 두류(5종), 견과 및 종실류(5종), 채소류(11종), 버섯류(10 종), 과일류(31종), 난류(12종), 유지류(1종), 차류(1종), 조 리가공식품류(1종), 식용곤충 등 기타(5종)의 총 96종이었 다. 확보된 시료는 국립농업과학원 기능성식품과(Wanju, Korea)에서 전처리 및 단순 가공 처리하여 균질화 과정을 거쳐 동결 후 배송되었으며, 배송된 시료는 $-70^{\circ} \mathrm{C}$ 냉동고 에서 저장하여 분석에 사용하였다.

\section{비타민 D 추출}

비타민 D 함량 분석을 위하여 균질화된 시료를 수산화칼 륨과 피로가롤·에탄올 용액을 이용하여 검화시킨 후 동시 추출하였다(18). 갈색 검화 플라스크에 균질화된 시료 1-3 $\mathrm{g}$ 을 정밀히 취한 후, $10 \%$ 피로가롤·에탄올 용액 $40 \mathrm{~mL}$ 을 가하여 약하게 진탕 혼합하였다. 여기에 $90 \%$ 수산화칼륨용 액 $10 \mathrm{~mL}$ 을 가하고 진탕 혼합하였다. 검화플라스크에 환류 냉각관을 부착하여 비등수욕 중에서 60 분간 가열하여 검화 하였다. 검화 완료한 시료는 즉시 실온으로 냉각하고 갈색 분액깔때기로 옮긴 후 헥산 $50 \mathrm{~mL}$ 을 가하여 10 분간 강하게 진탕 혼합하였다. 일정시간 방치하여 층 분리가 되면 상등 액은 수집하고 남은 하층에 헥산 $50 \mathrm{~mL}$ 을 가하여 2회 더 반복 추출하여 상등액을 수집하였다. 수집된 전체 상등액 에 $1 \mathrm{~N}$ 수산화칼륨용액 $100 \mathrm{~mL}$ 을 가하여 진탕혼합한 후 방치하여 층 분리를 진행 후 혼탁한 물층을 제거하였다. 헥산층에 $0.5 \mathrm{~N}$ 수산화칼륨용액 $40 \mathrm{~mL}$ 을 가하여 진탕한 후 방치하여 층 분리가 되면 물층은 다시 버리고 헥산층은 세척액이 페놀프타레인 시약에 알칼리반응이 나타나지 않 을 때까지 충분히 세척하였다. 수세가 끝난 헥산층은 무수 황산나트륨으로 탈수하여 갈색 감압농축플라스크에 옮겨 $40^{\circ} \mathrm{C}$ 이하에서 감압농축하였다. 농축하여 얻어진 잔류물에 메탄올 $2 \mathrm{~mL}$ 을 가하여 재용해시켜 $0.45 \mu \mathrm{m}$ membrane filter 로 여과한 후, 비타민 D 분석용 시험용액으로 사용하였다.

\section{비타민 D 분석방법}

비타민 D 분석은 시험용액을 HPLC-MS/MS(High performance liquid chromatography Mass Spectrometry, Triple Quad 4500 AB Sciex Instruments, Redwood city, CA, $\mathrm{USA}$ 로 분석하여 비타민 D2 및 D3 함량을 정량하였다. 분석조건으로는 $\mathrm{C}_{18}$ column(Kinetex $\mathrm{C}_{18}$, Phenomenex, Torrance, CA, USA)을 이용하여 이동상 $(5 \mathrm{mM}$ ammonium acetate:methanol $=5: 95)$ 을 $40^{\circ} \mathrm{C}$ 에서 $0.7 \mathrm{~mL} / \mathrm{min}$ 으로 흘려주 었으며, 질량분석기는 ESI positive 조건에서 capillary 온도 
$500^{\circ}$, collision 가스는 Ar, nebulizer 가스는 $\mathrm{N}_{2}$ 를 사용하였 다. 이때 모든 시료는 3 회 반복 분석하였으며, 비타민 D2 및 D3 함량의 평균값으로 나타내었다.

\section{비타민 $\mathrm{D}$ 분석법 검증}

본 실험의 유효성 검증을 위하여 직선성(linearity), 정확 도(accuracy), 정밀도(presision), 검출한계(limit of detection, LOD), 정량한계(limit of quantitation, LOQ) 및 회수율 (recovery)을 측정하였다. 직선성은 비타민 D2와 D3 표준용 액을 $5,10,50,100,150,200,500 \mathrm{ng} / \mathrm{mL}$ 의 농도가 되도록 메탄올에 희석한 후, LC-MS/MS에 주입하여 얻어진 피크면 적으로부터 검량선을 작성하고, 직선성 $(\mathrm{R} 2>0.98)$ 을 구하였 다. 정확도와 정밀성 평가를 위하여 정기적으로 표준인증 물질로 CRM(Certified Reference Material)인 SRM 1849a(Infant/Adult Nutritional Formula, NIST(National Institute of Standards and Technology), Gaithersburg, Maryland, USA)와 BCR-122(Margarine, IRMM(Institute for Reference Materials and Measurements), Geel, Belgium, EU) 를 이용하여 분석방법의 정확성 및 회수율을 검증하였다. 또한 기기검출한계와 정량한계를 구하기 위하여 비타민 $\mathrm{D} 2$ 와 D3 표준용액을 각각 $5 \mathrm{ng} / \mathrm{mL}$ 농도로 6 회 반복측정하 여 각각의 표준편차에 3 에 해당하는 농도를 검출한계로 하였으며, 10 에 해당하는 각각의 농도를 정량한계로 계산 하였다.

\section{비타민 D 분석 품질관리}

분석방법의 정밀도(precision)을 평가하기 위하여 품질관 리시료로 건조표고버섯과 브로콜리 및 조제분유를 매회 분석하여 분석결과에 대한 품질을 관리하였다. $95 \%$ 수준의 경고한계(2SD: standard deviation)를 넘을 경우 재분석으로 판정하였으며, $99 \%$ 수준의 조절한계(3SD)를 넘을 경우 실 험방법, 실험환경 등을 시정하여 허용범위에 들도록 관리 하였다.

\section{통계처리}

각 비타민 $\mathrm{D}$ 의 분석 정량 값은 IBM SPSS Statistics 25 (Statistical Analysis System, SAS Institute Inc., Cary, NC, USA)를 이용하여 시료간의 차이 유무를 분산분석 (ANOVA)을 시행한 후, Duncan's multiple range test $(\mathrm{p}<0.05)$ 를 실시하여 각 시료 간의 유의성을 검증하였다.

\section{결과 및 고찰}

\section{곡류 및 전분, 견과류의 비타민 $\mathrm{D}$ 함량}

일반 곡류 5 종, 곡류가공품 3 종, 전분류 1 종, 견과류 5 종 을 대상으로 분석한 비타민 D2 및 D3 함량의 평균값은
Table 1 과 같다. 세계 3 대 작물 중 하나인 옥수수는 단위면적 당 곡실 수량이 가장 많고 어디서나 쉽게 재배가 가능하기 때문에 오래전부터 주요 식량작물로 재배하여 왔다. 옥수 수의 종자에 따른 비타민 D 함량은 강다옥(건조)에서 비타 민 D2가 $4.11 \mu \mathrm{g} / 100 \mathrm{~g}$ 검출되었고 그 외 대학(생것, 삶은 것), 광평옥(건조), 다안옥(건조) 품종에서는 비타민 $\mathrm{D}$ 가 검출되지 않았다. 이는 옥수수 품종에 따라서 비타민 D 함량의 차이가 있었으며, 또한 광평옥, 강다옥 품종은 농촌 진흥청에서 사료용 옥수수로 개발되어 보급된 우수한 품종 으로(19) 특히 강다옥 품종에서 비교적 높은 비타민 D2 함량이 존재함을 알 수 있었다.

곡류가공품 중 도토리묵에서 $1.83 \mathrm{\mu g} / 100 \mathrm{~g}$ 의 비타민 D2 가 검출되었고, 견과류에서는 가공된 밤에서 $0.85 \mu \mathrm{g} / 100$ $\mathrm{g}$, 도토리묵 가루에서 $2.46 \mu \mathrm{g} / 100 \mathrm{~g}$ 의 비타민 D2가 검출되 었고 그 외 시료에서는 검출되지 않았다. 특히 도토리묵과 도토리묵 가루에서 비타민 D2가 확인되었고, 그 중 도토리 묵 가루에서 더 높은 비타민 D2 함량을 나타내었다. 이는 도토리묵에서 낮은 비타민 $\mathrm{D} 2$ 함량이 검출된 것은 원료 내의 다량의 수분함량에 기인한 것으로 판단되었다.

\section{당류, 두류, 유지류, 차류 및 조리가공식품류의 비타민 D 함량}

당류 5 종, 두류 5 종, 유지류 1 종, 차류 1 종, 조리가공식품 류 1종을 대상으로 비타민 D2 및 D3 함량을 분석한 결과는 Table 2 와 같다. 당류 중 땅콩 카라멜 함유 초코바, 쿠키 카라멜 함유 초코바 및 라이스 시리얼 함유 초코바에서 비타민 D2 함량이 각각 $3.39 \mathrm{\mu g} / 100 \mathrm{~g}, 2.22 \mathrm{\mu g} / 100 \mathrm{~g}, 5.50$ $\mu \mathrm{g} / 100 \mathrm{~g}$ 로 검출되었으나, 젤리 및 초콜릿은 비타민 D2가 검출되지 않았다. Kuhn 등(20)의 연구결과에 따르면 4종의 코코아 제품과 9 종의 코코아 기반 식품의 비타민 $\mathrm{D}$ 를 분석 한 결과, 4종의 코코아 제품 중 코코아 파우더에서 $2.98 \pm 1.65 \mathrm{\mu g} / 100 \mathrm{~g}$, 다크 초콜릿에서 $3.95 \pm 1.58 \mathrm{\mu g} / 100 \mathrm{~g}$ 으 로 비타민 D2가 가장 높은 함량을 나타내었다. 그러나 본 연구에서는 초콜릿에서는 비타민 D2가 검출되지 않았고, 초코바(땅콩, 쿠키, 라이스 시리얼)에서 비타민 D2가 검출 되었다. 이는 초콜릿 내의 코코아 함량에 의한 차이로 인해 검출되지 않은 것으로 생각되며, 또한 초코바의 경우 땅콩, 쿠키, 라이스 시리얼의 함유와 함께 코코아 함량의 차이로 인해 비타민 D2 함량이 검출된 것으로 사료되었다. 이는 코코아 콩 자체에 비타민 D2의 전구체인 ergosterol를 함유 하고 있어, 코코아기반 식품에서도 비타민 $\mathrm{D}$ 를 함유하고 있다고 보고와 유사한 경향이었다(20).

또한 두류 중 팥빙수용 팥에서 $1.52 \mu \mathrm{g} / 100 \mathrm{~g}$ 의 비타민 $\mathrm{D} 2$ 가 검출되었고, 특히 두유에서는 비타민 $\mathrm{D} 2$ 와 $\mathrm{D} 3$ 의 함 량은 각각 $5.30 \mu \mathrm{g} / 100 \mathrm{~g}, 0.83 \mu \mathrm{g} / 100 \mathrm{~g}$ 로 나타났다. 반면에 연두부, 녹두묵, 냉동유부, 현미유, 녹차라떼, 잣죽, 두부, 팥묵, 동결건조 두부에서는 비타민 $\mathrm{D}$ 가 불검출 되었다. 미 
국, 케나다, 유럽에서 일일 비타민 D 섭취량은 $15 \mu$ $\mathrm{g} / \mathrm{day}(600 \mathrm{IU})$, 영국은 $10 \mu \mathrm{g} / \mathrm{day}(400 \mathrm{IU})$ 로 70세 이하의 모든 연령에 대하여 권고하고 있다(21). 그러므로 콩류 가공 식품 중에서 두유와 초콜릿 가공제품은 부분적으로 비타민 $\mathrm{D}$ 를 보충할 수 있는 우수한 식품소재로 판단되었다.

\section{채소류 및 버섯류의 비타민 D 함량}

채소류 11 종과 버섯류 10 종을 대상으로 비타민 D2와 D3 함량을 분석한 결과는 Table 3과 같다. 아스파라거스(생 것, 데친것), 비트(생것, 데친것), 산마늘 장아찌, 락교, 콜리 플라워(생것, 데친것), 무씨싹(생것), 바질잎(생것, 데친 것)

Table 1. Vitamin D contents in cereals, potato, nuts and seed

\begin{tabular}{|c|c|c|c|c|}
\hline \multicolumn{3}{|c|}{ Sample } & $\begin{array}{l}\text { Vitamin D2 } \\
(\mu \mathrm{g} / 100 \mathrm{~g})\end{array}$ & $\begin{array}{l}\text { Vitamin D3 } \\
(\mu \mathrm{g} / 100 \mathrm{~g})\end{array}$ \\
\hline \multirow{8}{*}{ Cereals (8) } & & Acorn jelly & $1.83 \pm 0.42^{\mathrm{al})}$ & N. $D^{2)}$ \\
\hline & & Baekseolgi & N.D & N.D \\
\hline & \multirow{6}{*}{ Corn } & Prepared / Popcorn & N.D & N.D \\
\hline & & Kangdaok / Dry & $4.11 \pm 0.51^{\mathrm{a}}$ & N.D \\
\hline & & Gwangpyeongok / Dry & N.D & N.D \\
\hline & & Daanok / Dry & N.D & N.D \\
\hline & & Zea mays L. (Daehak) Raw & N.D & N.D \\
\hline & & Zea mays L. (Daehak) Boiled & N.D & N.D \\
\hline Potato (1) & & Sweet potato starch powder & N.D & N.D \\
\hline \multirow{5}{*}{$\begin{array}{l}\text { Nuts and } \\
\text { seed (5) }\end{array}$} & & Chestnut, Prepared & $0.85 \pm 0.22^{\mathrm{a}}$ & N.D \\
\hline & & Acorn jelly powder & $2.46 \pm 1.23^{\mathrm{a}}$ & N.D \\
\hline & & Pistachoi, Salted \& Roast & N.D & N.D \\
\hline & & Sunflower, Seed \& Raw & N.D & N.D \\
\hline & & Peanut, Season & N.D & N.D \\
\hline
\end{tabular}

${ }^{1)}$ All values are expressed as the mean \pm SD of triplicate determinations.

${ }^{2)}$ N.D: Not Detected.

${ }^{a}$ Values with different superscripts within the same column are significantly different by Duncan's multiple range test at $p<0.05$.

Table 2. Vitamin D contents in sugars, sweeteners, pulses, oils, teas, prepared foods

\begin{tabular}{|c|c|c|c|}
\hline & Sample & $\begin{array}{l}\text { Vitamin D2 } \\
(\mu \mathrm{g} / 100 \mathrm{~g})\end{array}$ & $\begin{array}{l}\text { Vitamin D3 } \\
(\mu \mathrm{g} / 100 \mathrm{~g})\end{array}$ \\
\hline \multirow{5}{*}{$\begin{array}{c}\text { Sugars and } \\
\text { sweeteners (5) }\end{array}$} & Chocobar, Peanut caramel & $3.39 \pm 0.15^{\mathrm{al})}$ & N.D ${ }^{2)}$ \\
\hline & Chocobar, Cookie caramel & $2.22 \pm 0.12^{\mathrm{a}}$ & N.D \\
\hline & Chocobar, Rice cereals & $5.50 \pm 1.59^{\mathrm{a}}$ & N.D \\
\hline & Jelly & N.D & N.D \\
\hline & Chocolate & N.D & N.D \\
\hline \multirow{5}{*}{ Pulses (5) } & Adzuki beans, Patbingsu & $1.52 \pm 0.12^{\mathrm{a}}$ & $N \cdot D^{a}$ \\
\hline & Soy milk & $5.30 \pm 1.93^{\mathrm{a}}$ & $0.83 \pm 0.19^{\mathrm{a}}$ \\
\hline & Soft tofu & N.D & N.D \\
\hline & Mung beans muk & N.D & N.D \\
\hline & Freeze fried tofu & N.D & N.D \\
\hline Oil (1) & Brown rice oil & N.D & N.D \\
\hline Tea (1) & Green tea Latte & N.D & N.D \\
\hline Prepared foods (1) & Pine nut Porridge & N.D & N.D \\
\hline
\end{tabular}

\footnotetext{
${ }^{1)}$ All values are expressed as the mean $\pm \mathrm{SD}$ of triplicate determinations.
}

${ }^{2)}$ N.D: Not Detected.

${ }^{a}$ Values with different superscripts within the same column are significantly different by Duncan's multiple range test at $p<0.05$. 
Table 3. Vitamin D contents in vegetables and mushrooms

\begin{tabular}{|c|c|c|c|c|}
\hline \multicolumn{3}{|c|}{ Sample } & $\begin{array}{l}\text { Vitamin D2 } \\
(\mu \mathrm{g} / 100 \mathrm{~g})\end{array}$ & $\begin{array}{l}\text { Vitamin D3 } \\
(\mu \mathrm{g} / 100 \mathrm{~g})\end{array}$ \\
\hline \multicolumn{3}{|c|}{ Asparagus, Raw } & N.D & N.D ${ }^{2)}$ \\
\hline \multicolumn{3}{|c|}{ Asparagus, Boiled } & N.D & N.D \\
\hline \multirow{9}{*}{$\begin{array}{l}\text { Vegetables } \\
\text { (11) }\end{array}$} & \multicolumn{2}{|c|}{ Beet, Root \& Raw } & N.D & N.D \\
\hline & \multicolumn{2}{|c|}{ Beet, Root \& Boiled } & N.D & N.D \\
\hline & \multicolumn{2}{|c|}{ Pickled Allium victorialis } & N.D & N.D \\
\hline & \multicolumn{2}{|c|}{ Rakyo } & N.D & N.D \\
\hline & \multicolumn{2}{|c|}{ Cauliflower, Raw } & N.D & N.D \\
\hline & \multicolumn{2}{|c|}{ Cauliflower, Boiled } & N.D & N.D \\
\hline & \multicolumn{2}{|c|}{ Radish seed sprout, \& Raw } & N.D & N.D \\
\hline & \multicolumn{2}{|c|}{ Basil leaves, Raw } & N.D & N.D \\
\hline & \multicolumn{2}{|c|}{ Basil leaves, Boiled } & N.D & N.D \\
\hline \multirow{10}{*}{$\begin{array}{l}\text { Mushrooms } \\
\text { (10) }\end{array}$} & \multirow{3}{*}{$\begin{array}{c}\text { Oyster } \\
\text { mushroom }\end{array}$} & Raw & $3.85 \pm 0.67^{\mathrm{a} 1)}$ & $3.54 \pm 0.46^{\mathrm{a}}$ \\
\hline & & Hot-air drying & $6.04 \pm 0.12^{\mathrm{a}}$ & $2.75 \pm 0.15^{\mathrm{a}}$ \\
\hline & & Natural drying & $644.72 \pm 45.31^{\mathrm{b}}$ & N.D $D^{\mathrm{a}}$ \\
\hline & \multirow{3}{*}{$\begin{array}{c}\text { Cordyceps } \\
\text { militaris }\end{array}$} & Oats / Raw & $3.38 \pm 0.60^{\mathrm{a}}$ & $N . D^{\mathrm{a}}$ \\
\hline & & Pupa / Raw & $8.22 \pm 1.79^{\mathrm{a}}$ & $1.89 \pm 0.83^{\mathrm{a}}$ \\
\hline & & Brown rice / Raw & $3.15 \pm 1.25^{\mathrm{a}}$ & N.D \\
\hline & \multirow{2}{*}{$\begin{array}{l}\text { Hericium } \\
\text { erinaceum }\end{array}$} & Raw & $1.14 \pm 0.04^{\mathrm{a}}$ & N.D \\
\hline & & Boiled & N.D & N.D \\
\hline & \multirow{2}{*}{$\begin{array}{l}\text { Pleurotus } \\
\text { ferules }\end{array}$} & Raw & $7.15 \pm 1.78^{\mathrm{a}}$ & N.D \\
\hline & & Boiled & N.D & N.D \\
\hline
\end{tabular}

${ }^{1)}$ All values are expressed as the mean \pm SD of triplicate determinations.

${ }^{2}$ N.D: Not Detected.

${ }^{a, b}$ Values with different superscripts within the same column are significantly different by Duncan's multiple range test at $p<0.05$

등 11 종의 채소류에서는 비타민 $\mathrm{D}$ 가 모두 검출되지 않았다. 반면에 버섯류에서는 노루궁뎅이버섯(데친 것)과 아위버 섯(데친 것)을 제외한 모든 버섯에서 비타민 $\mathrm{D}$ 함량이 검출 되었다.

먼저 느타리버섯(생것), 느타리버섯(열풍건조), 느타리 버섯(자연건조)에서 비타민 D2 함량이 3.85-644.72 $\mu \mathrm{g} / 100$ $\mathrm{g}$ 범위로 나타났으며, 생것보다 건조 후에 비타민 $\mathrm{D} 2$ 의 함량이 약 1.5-160배로 크게 증가하는 것으로 나타났다. 즉 열 풍건조(느타리버섯)와 자연건조(느타리버섯)에 의해 서 각각 $6.04 \mu \mathrm{g} / 100 \mathrm{~g}, 644.72 \mu \mathrm{g} / 100$ 으로 비타민 D2의 함량 의 큰 차이를 보이면서 자연건조한 느타리버섯이 영양학적 으로 중요한 비타민 $\mathrm{D} 2$ 를 고농도 함유한 식품 소재로 판단 되었다. 그러나 비타민 D3 함량은 느타리버섯(생것)에서 $3.54 \mathrm{\mu g} / 100 \mathrm{~g}$, 느타리버섯(열풍건조)에서 $2.75 \mu \mathrm{g} / 100 \mathrm{~g}$ 으 로 약간 감소되었으며, 느타리버섯(자연건조)에서는 검출 되지 않았다. 이는 느타리버섯 내에 존재하던 미량의 비타 민 D3 함량이 건조과정을 거치면서 파괴되는 것으로 생각 되었고, 특히 열풍건조보다 오랜 시간이 소요되는 자연건 조 방식으로 생산된 느타리버섯에서 비타민 D3가 더 크게
손상된 것으로 사료되었다. 또한 Choi(22)의 연구에서 느타 리버섯을 포함한 7종의 버섯에서 자외선조사에 의해 비타 민 D2의 함량이 크게 증가하고, 특히 팽이버섯과 느타리버 섯(갓)에서 비타민 D2의 함량이 크게 증가하였으며, 버섯 의 표면적과 비타민 $\mathrm{D} 2$ 의 합성에는 연관성이 있다고 보고 하였다. 본 연구에서도 생 느타리버섯보다 건조한 느타리 버섯에서 비타민 D2의 함량이 크게 증가하였고, 특히 자연 건조한 느타리버섯에서 약 160 배로 비타민 D2의 함량이 크게 증가하는 유사한 경향을 보임을 확인하였다.

동충하초는 배지로 사용된 원료에 따라 귀리 동충하초, 번데기 동충하초, 현미 동충하초 3 종에 대해 비타민 D 함량 을 분석하였다. 3 종의 동충하초(생것)에서 비타민 D2가 3.15-8.22 $\mu \mathrm{g} / 100 \mathrm{~g}$ 함량으로 검출되었고, 번데기 동충하초 에서는 비타민 D3 함량도 $1.89 \mu \mathrm{g} / 100 \mathrm{~g}$ 검출되었다. 또한 노루궁뎅이버섯(생것)에서 비타민 D2가 $1.14 \mathrm{\mu g} / 100 \mathrm{~g}$ 으로 검출되었고, 아위버섯(생것)에서도 비타민 $\mathrm{D} 2$ 가 $7.15 \mu$ $\mathrm{g} / 100 \mathrm{~g}$ 으로 나타났다. 반면에 노루궁뎅이버섯(데친 것) 및 아위버섯(데친 것)에서는 불검출로 나타났으며 이는 공기 중 산소에 의해 산화작용이 일어나 비타민 D2가 검출되지 
않은 것(23)으로 판단되며, 또한 데치는 과정에 의한 높은 수분함량에 의해서 검출되지 않은 것으로 판단되었다.

Krzyczkowski 등(24)의 연구에 따르면 건조된 노루궁뎅 이버섯에서 ergosterol peroxide의 함량이 $16 \pm 0.78 \mathrm{mg} / 100$ $\mathrm{g}$ 으로 나왔으며, Yokoyama 등(25)의 연구에서는 아위버섯 에탄올 추출물에서 ergosterol peroxide의 함량이 $18 \mathrm{mg}$ 함 유되어있다고 보고하였다. Ergosterol은 비타민 D2의 전구 물질로 생육방법, 보관방법 등에 따라 일부 비타민 D2로
전환되므로, 본 연구에서도 노루궁뎅이버섯과 아위버섯의 생것에서 비타민 D2가 존재함을 알 수 있었다.

\section{과일류, 난류 및 기타 식품의 비타민 D 함량}

과일류 31종(오미자청, 매실청, 감귤류 4종, 포도류 24종, 사과주스 1 종)의 비타민 $\mathrm{D} 2$ 와 D3함량을 분석한 결과는 Table 4와 같다. 그 결과, 오미자청에서는 비타민 D2가 1.28 $\mu \mathrm{g} / 100 \mathrm{~g}$ 검출되었으며, 감귤류 중 하례조생, 궁천조생 및

Table 4. Vitamin D contents in fruits

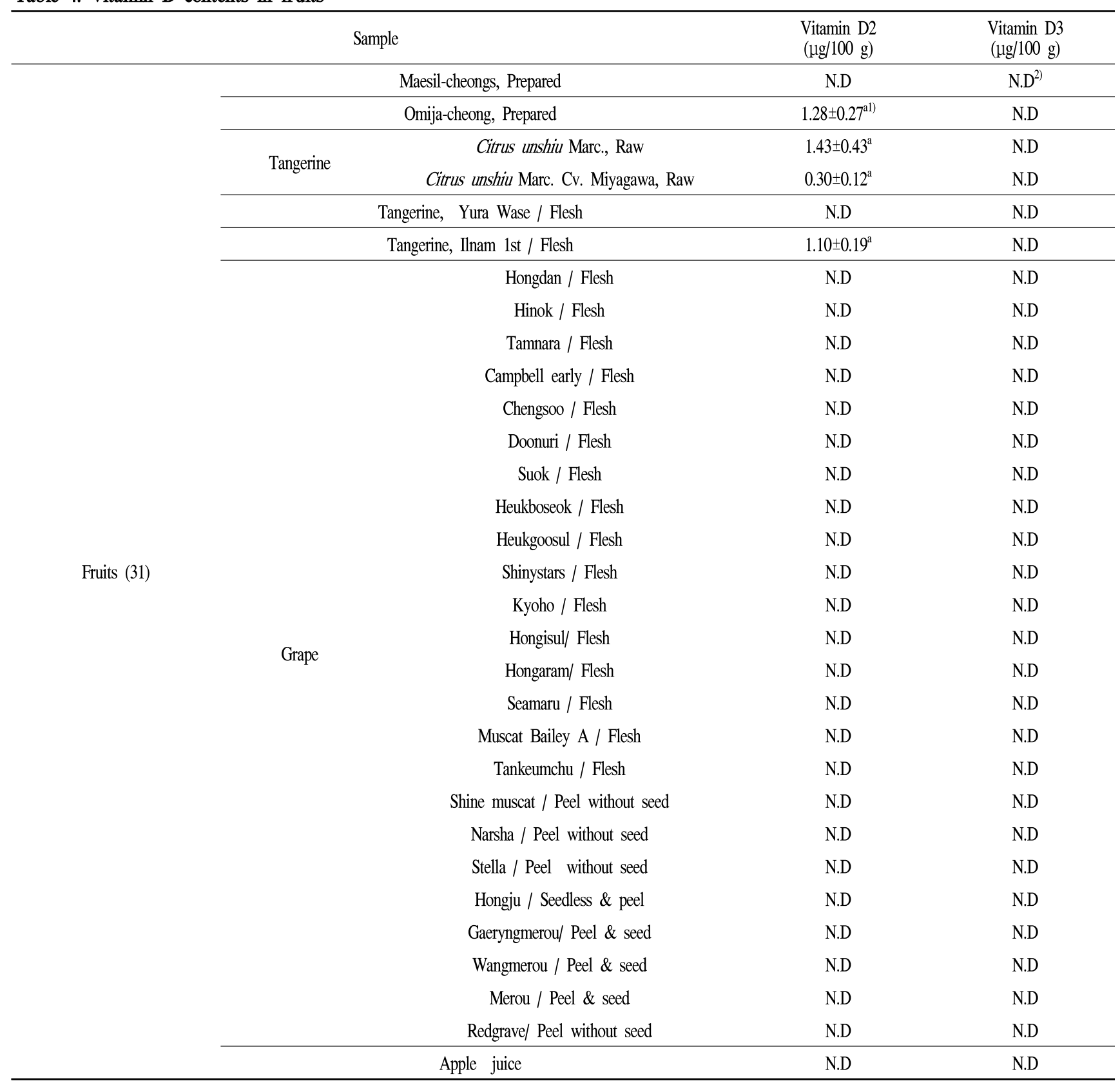

\footnotetext{
${ }^{1)}$ All values are expressed as the mean $\pm \mathrm{SD}$ of triplicate determinations.

${ }^{2)}$ N.D: Not Detected.

${ }^{a, b}$ Values with different superscripts within the same column are significantly different by Duncan's multiple range test at $p<0.05$.
} 
일남 1 호에서 $0.30-1.43 \mu \mathrm{g} / 100 \mathrm{~g}$ 의 비타민 D2가 검출되었 다. 반면에 매실청, 귤(유라조생), 사과주스 그리고 홍단, 진옥 등의 국내 및 국외 포도류 품종 24종에서는 비타민 $\mathrm{D}$ 가 검출되지 않았다. 국내에서 가장 많이 재배되고 있는 품종인 온주밀감류에서 농촌진흥청이 개발해 보급한 신품 종인 하례조생은 당도가 높고 신맛을 내는 품종으로 비타민 $\mathrm{D} 2$ 함량도 $1.43 \mu \mathrm{g} / 100 \mathrm{~g}$ 으로 가장 높은 값을 나타내었고, 감귤 일남1호의 과육부분에서도 $1.10 \mu \mathrm{g} / 100 \mathrm{~g}$ 의 비타민 D2 함량을 나타내었다. 지금까지 감귤류에 대한 비타민 $\mathrm{D}$ 함량이 검출된 연구 보고는 없는 실정으로, 본 연구에서 는 LCMS 분석기술을 적용하여 미량의 비타민 $\mathrm{D}$ 의 분석이 가능해 짐으로서, 국내에서 재배되는 감귤 품종에 따른 비 타민 $\mathrm{D} 2$ 가 미량 검출되어진 것으로 사료된다.

그리고 난류 12 종 및 기타 식품 5 종의 비타민 D2와 D3 함량을 분석한 결과는 Table 5 와 같다. 먼저 난류는 메추리
알, 달걀, 오리알을 난백과 난황으로 분류하고 생것과 삶은 것으로 구분하여 각각 분석하였다. 그 결과 모든 난류의 난백에서는 비타민 $\mathrm{D}$ 가 검출되지 않았으나, 난황에서는 메추리알, 오리알, 달걀 순으로 비타민 D3 함량이 높은 값을 보였다. 즉 메추리알의 난황에서 $3.59-4.99 \mathrm{\mu g} / 100 \mathrm{~g}$, 오리알 의 난황에서는 $20.85-22.30 \mu \mathrm{g} / 100 \mathrm{~g}$, 달걀의 난황에서는 63.96-95.04 $\mathrm{\mu g} / 100 \mathrm{~g}$ 으로 가장 높은 함량의 비타민 D3를 함유하였다. 또한 메추리알, 오리알 및 달걀의 난황을 생것 과 삶은 것으로 구분하여 비타민 D3 함량을 비교하면 알의 종류에 관계없이 열처리된 난황(삶은 것)에서 비타민 D3 함량이 더 증가하는 경향을 보였다. Schmid와 Walther (26) 의 연구에서 동물성 식품 중 달걀의 노른자에서 비타민 $\mathrm{D} 3$ 의 함량은 0-56 $\mathrm{\mu g} / \mathrm{kg}$, 달걀 전체의 비타민 D3의 함량은 0-30 $\mu \mathrm{g} / \mathrm{kg}$ 으로 보고하였는데, 국내에서 생산된 계란의 난 황에서 비타민 D3가 63.96-95.04 $\mathrm{\mu g} / 100 \mathrm{~g}$ 로 더 높은 값을

Table 5. Vitamin D contents in eggs and others

\begin{tabular}{|c|c|c|c|c|}
\hline \multicolumn{3}{|c|}{ Sample } & $\begin{array}{l}\text { Vitamin D2 } \\
(\mu \mathrm{g} / 100 \mathrm{~g})\end{array}$ & $\begin{array}{l}\text { Vitamin D3 } \\
(\mu \mathrm{g} / 100 \mathrm{~g})\end{array}$ \\
\hline \multirow{12}{*}{ Eggs (12) } & \multirow{4}{*}{ Quail's egg } & Albumin, Raw & N.D & N.D \\
\hline & & Albumin, Boiled & N.D & N.D \\
\hline & & Yolk, Raw & N.D & $3.59 \pm 1.07^{11)}$ \\
\hline & & Yolk, Boiled & N.D & $4.99 \pm 1.30^{\mathrm{a}}$ \\
\hline & \multirow{4}{*}{ Egg } & Albumin, Boiled & N.D & N.D \\
\hline & & Albumin, Raw & N.D & N.D \\
\hline & & Yolk, Raw & N.D & $63.96 \pm 10.20^{\circ}$ \\
\hline & & Yolk, Boiled & N.D & $95.04 \pm 7.74^{\mathrm{d}}$ \\
\hline & \multirow{4}{*}{ Duck's egg } & Albumin, Raw & N.D & N.D \\
\hline & & Albumin, Boiled & N.D & N.D \\
\hline & & Yolk, Raw & N.D & $20.85 \pm 0.84^{b}$ \\
\hline & & Yolk, Boiled & N.D & $22.30 \pm 0.15^{b}$ \\
\hline \multirow{5}{*}{ Other (5) } & \multicolumn{2}{|c|}{ Gryllus bimaculatus, Imago / Flesh } & N.D & N.D \\
\hline & \multirow{2}{*}{ Silkworm } & Pupa / Flesh & N.D & N.D \\
\hline & & Larva / Dry & N.D & N.D \\
\hline & \multicolumn{2}{|c|}{ Rice grasshopper, Imago / Flesh } & N.D & N.D \\
\hline & \multicolumn{2}{|c|}{ Allomyrina dichotoma, Larva / Dry } & N.D & N.D \\
\hline
\end{tabular}

${ }^{1)}$ All values are expressed as the mean $\pm \mathrm{SD}$ of triplicate determinations.

${ }^{2)}$ N.D: Not Detected.

${ }^{a e}$ Values with different superscripts within the same column are significantly different by Duncan's multiple range test at $p<0.05$.

Table 6. Comparison between the analyzed vitamin $\mathrm{D}$ values and the reference values

\begin{tabular}{cccccc}
\hline CRM $^{1)}$ & Matrix & Analysis value $(\mathrm{mg} / \mathrm{kg})$ & Reference value $(\mathrm{mg} / \mathrm{kg})$ & $\begin{array}{c}\text { Recovery } \\
(\%)\end{array}$ & RSD $^{2)}(\%)$ \\
\hline SRM1849 & Infant formula & $0.119 \pm 0.001$ & $0.11 \pm 0.02$ & 108.18 & 0.84 \\
\hline BCR-122 & Margarine & $0.125 \pm 0.002$ & $0.13 \pm 0.01$ & 96.15 & 1.60 \\
\hline
\end{tabular}

${ }^{1)}$ CRM: Certified Reference Material.

${ }^{2}$ RSD: Relative Standard Deviation. 
나타내었다. 이는 LC/MS의 분석기술을 적용하여 아주 미 량의 비타민 $\mathrm{D}$ 의 분석이 가능해짐으로서 얻어진 결과로 사료된다. 또한 메추리알, 오리알, 달걀에서 모두 생 난황보 다 삶은 난황에서 비타민 D3의 함량이 더 높게 나타난다.

비타민 D가 풍부한 계란의 영양성분은 양계사료의 조성 과 관련이 있어 사료에 비타민을 첨가함으로써 계란의 비타 민을 강화하는 연구가 보고되었다(27). 즉 비타민 D가 강화 된 양계 사료를 섭취한 닭으로부터 얻어진 계란은 최고 $500 \mathrm{IU}$ 비타민 D를 함유하고 있어서 하루 성인의 비타민 $\mathrm{D}$ 요구량을 제공할 수 있다고 한다. 또한 닭의 사육에서 제공되는 사료뿐만 아니라 닭의 품종, 사육조건 등에 따라 서 비타민 $\mathrm{D}$ 를 포함한 계란의 성분에 차이가 있을 수 있다 고 하겠다. 따라서 국민 다소비 식품 중 비타민 D3가 가장 많이 함유된 식품은 계란의 난황이었고, 국내에서 생산된 달갈 내에 비타민 D 함량도 매우 높음을 알 수 있었다. 따라서 1 일 섭취량이 $15 \mu \mathrm{g}$ 인 미국 권장량을 기준으로 하루 에 달걀 1 개의 섭취는 우리 몸에서 필요로 하는 비타민 $\mathrm{D}$ 를 충분히 공급할 수 있다고 판단되었다.

그리고 미래 식량자원으로 각광 받고 있는 식용곤충(쌍 벌귀뚜라미, 누에 번데기, 누에유충, 벼메뚜기, 장수풍뎅이)
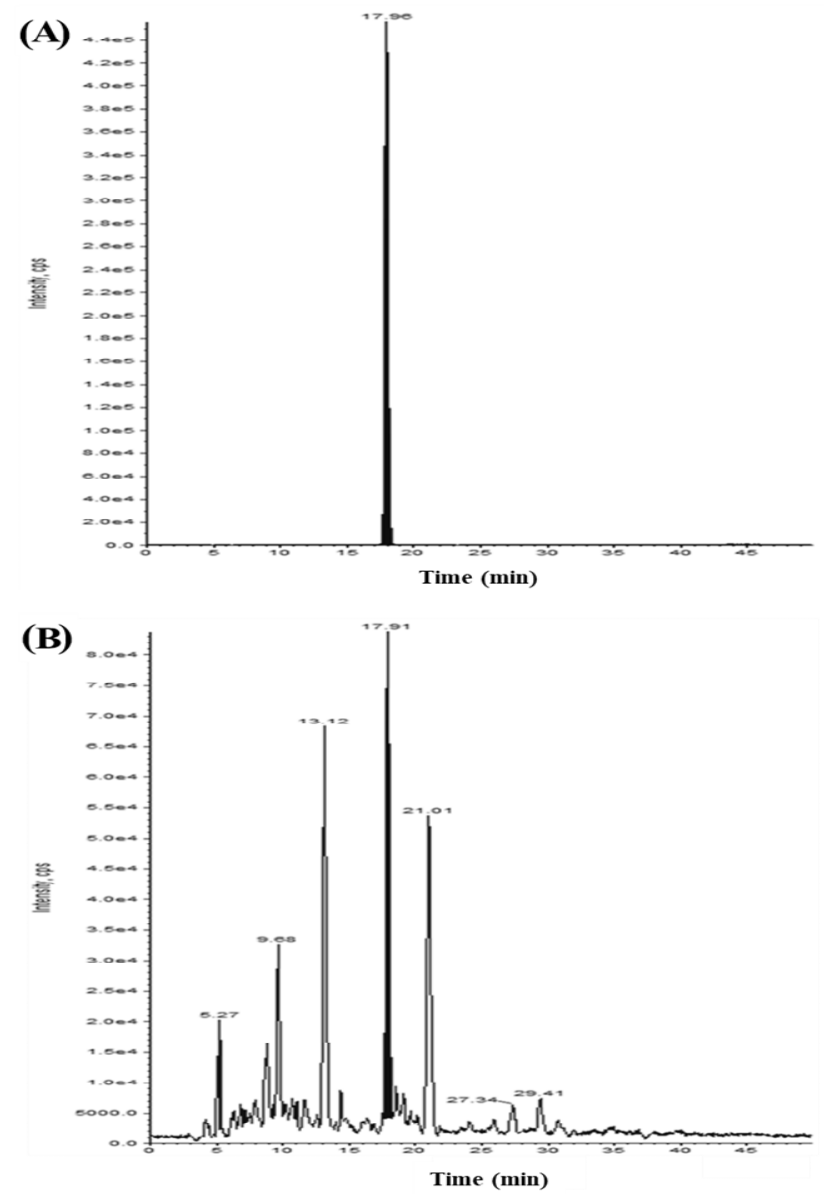

Fig. 1. HPLC chromatogram of (A) vitamin D standard and (B) SRM 1849a.
을 포함하는 기타 식품류에서는 비타민 D 함량이 검출되지 않았다.

식용곤충으로 쌍벌귀뚜라미는 단백질 함량이 $64 \%$ 이상 으로 고단백질 식품이며 지방 함량 중에서 불포화지방산 함량이 $60 \%$ 이상을 함유하는 유용한 식품소재이다(28). 식용곤충의 양식이 주로 실내에서 이루어져 비타민 D 합성 이 제대로 이루어지지 않아, 식용곤충에서 비타민 $\mathrm{D}$ 가 검출 되지 않은 것으로 사료된다.

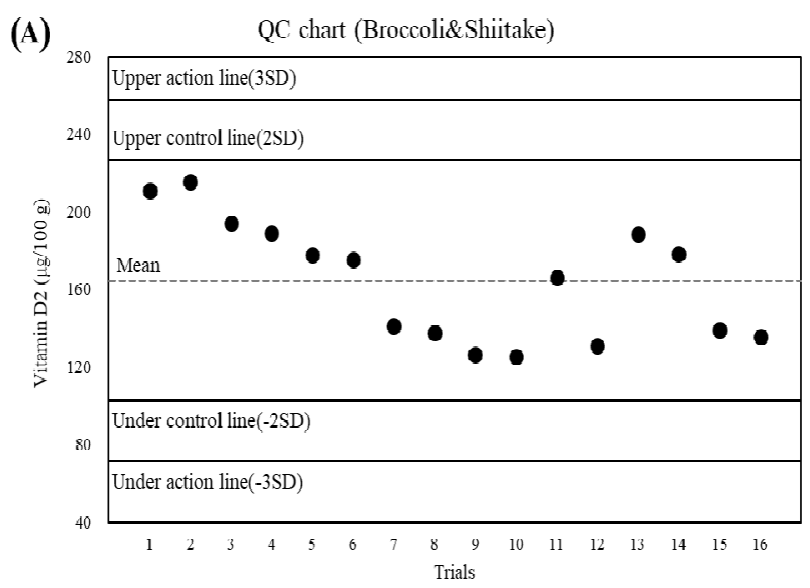

(B)

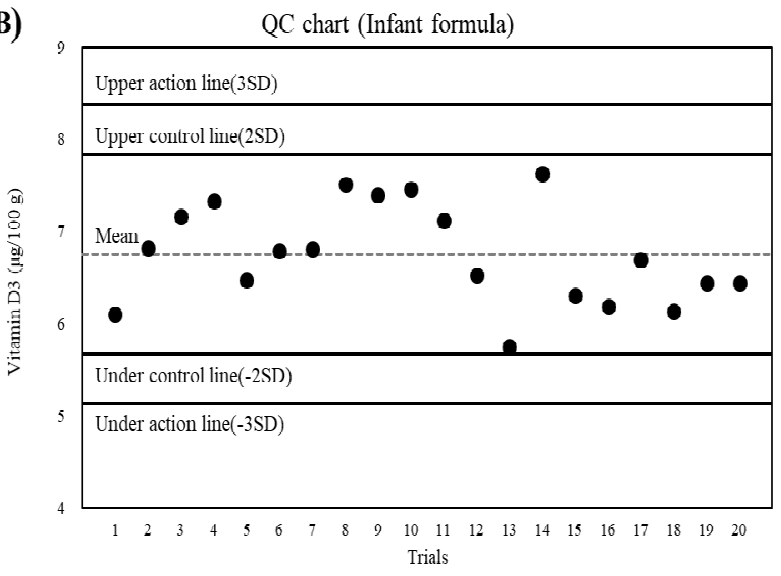

Fig. 2. Quality control (QC) chart of (A) broccoli \& shiitake (vitamin D2), and (B) infant formula (vitamin D3) for accuracy of vitamin $\mathrm{D}$ analysis.

when QC values deviate outside the 3SD confidence interval or showed a trend, the analytical run was rejected and corrective action taken.

\section{비타민 $\mathrm{D}$ 의 내부 분석품질관리}

비타민 D 분석방법에 대한 유효성을 검증하기 위해, 참 값이 알려진 SRM 1849a(Infant/Adult Nutritional formula)와 BCR-122(Margarine)를 이용하여 비타민 $\mathrm{D}$ 의 회수율 및 정 확성을 확인하였다. 그 결과 Table 6 및 Fig. 1과 같이, 비타 민 $\mathrm{D}$ 의 회수율은 $96.15-108.18 \%$ 이었고 RSD는 $0.84-1.60 \%$ 로 분석에 대한 높은 정확성을 확인하였다. 또한 비타민 $\mathrm{D} 2$ 및 $\mathrm{D} 3$ 에 대한 $\mathrm{LOD}$ 는 각각 $2.052 \mu \mathrm{g} / \mathrm{kg}, 1.312 \mu \mathrm{g} / \mathrm{kg}$ 이었 
고, $\mathrm{LOQ}$ 는 각각 $6.840 \mu \mathrm{g} / \mathrm{kg}, 4.372 \mu \mathrm{gg} / \mathrm{kg}$ 으로 측정되었다. 그리고 비타민 $\mathrm{D}$ 분석 값의 품질관리를 위해 분석품질관리 도표(QC 차트)를 작성하여 분석 결과에 대한 신뢰도를 검 증하였다(Fig. 2). 즉 분유(비타민 D3)와 브로콜리, 표고버 섯 가루(비타민 D2)를 16 회 이상 반복하여 비타민 $\mathrm{D}$ 를 분석 한 결과, 모든 데이터가 경고한계 범위 내로 유지되어 분석 품질에 대한 신뢰도를 확인하였다(Fig. 2).

\section{요 약}

비타민 D 함량을 LC-MS/MS를 이용하여 96종의 다소비 식품 중 곡류 및 관련제품(8종), 감자 및 전분류(1종), 당류(5 종), 두류(5종), 견과 및 종실류(5종), 채소류(11종), 버섯류 (10종), 과일류(31종), 난류(12종), 유지류(1종), 차류(1종), 조리가공식품류(1종), 식용곤충 등 기타(5종)를 분석한 결 과, 25 종에서 비타민 $\mathrm{D}$ 가 검출되었다. 전체 시료 중 버섯류 의 가장 많은 종에서 비타민 D가 검출되었으며, 그중 느타 리버섯 생것(D2 $3.85 \mu \mathrm{g} / 100 \mathrm{~g}, \mathrm{D} 33.54 \mu \mathrm{g} / 100 \mathrm{~g})$ 보다 열풍 건조(D2 $6.04 \mu \mathrm{g} / 100 \mathrm{~g}, \mathrm{D} 32.75 \mu \mathrm{g} / 100 \mathrm{~g}$ )에서 비타민 D 함량이 증가하였으며, 특히 자연건조 시 비타민 D2가 약 100 배(D2 $644.72 \mathrm{\mu g} / 100 \mathrm{~g}$ ) 증가하였다. 또한 동충하초(귀 리, 번데기, 현미)에서 비타민 D2가 3.15-8.22 $\mathrm{\mu g} / 100 \mathrm{~g}$ 로 함유되었고, 노루궁뎅이버섯(생것) 및 아위버섯(생것)의 비타민 D2 함량이 각각 $1.14 \mathrm{\mu g} / 100 \mathrm{~g}$ 및 $7.15 \mu \mathrm{g} / 100 \mathrm{~g}$ 로 검출되었으며, 동충하초(번데기)에서는 비타민 D3가 1.89 $\mu \mathrm{g} / 100 \mathrm{~g}$ 검출되었다. 곡류 및 그 제품군에서 도토리묵(D2 $1.83 \mu \mathrm{g} / 100 \mathrm{~g}$ )과 강다옥 옥수수(D2 $4.11 \mathrm{\mu g} / 100 \mathrm{~g}$ )에서, 두류 중 팥빙수용 팥(D2 $1.52 \mu \mathrm{g} / 100 \mathrm{~g})$ 과 두유(D2 5.30 $\mu \mathrm{g} / 100 \mathrm{~g}, \mathrm{D} 30.83 \mu \mathrm{g} / 100 \mathrm{~g}$ )에서 비타민 D가 검출되었다. 과일류에서는 오미자청과 감귤류에서 비타민 D2가 0.30-1.43 $\mathrm{\mu g} / 100 \mathrm{~g}$ 로 미량 함유하고 있었으며, 초코바(땅콩 카라멜, 쿠키 카라멜, 라이스 시리얼)에서는 비타민 D2가 2.22-5.50 $\mathrm{\mu g} / 100 \mathrm{~g}$ 검출되었다. 난류에서는 메추리알, 오리 알, 달걀의 모든 난황에서 비타민 D3가 3.59-95.04 $\mu \mathrm{g} / 100$ $\mathrm{g}$ 검출되었으며, 메추리알, 오리알, 달걀 순으로 비타민 D3 의 함량이 증가하였으며, 특히 달걀 난황(생것, 삶은 것)에 서 비타민 D3가 63.96-95.04 $\mu \mathrm{g} / 100 \mathrm{~g}$ 으로 가장 높은 함량이 검출되었다.

\section{감사의 글}

본 연구는 농촌진흥청 공동연구사업(과제번호. PJ01339808) 이 지원에 의해 이루어진 것으로 감사드립니다.

\section{References}

1. Choi HJ (2011) New insight into the action of vitamin D. Korean J Fam Med, 32, 89-96

2. Holick MF (2004) Sunlight and vitamin D for bone health and prevention of autoimmune diseases, cancers, and cardiovascular disease. Am J Clin Nutr, 80, 1678-1688

3. Norman AW (2008) From vitamin D to hormone D: fundamentals of the vitamin D endocrine system essential for good health. Am J Clin Nutr, 88, 491-499

4. Plum LA, Deluca HF (2010) Vitamin D, disease and therapeutic opportunities. Nat Rev Drug Discov, 9, 941-955

5. Prietl B, Treiber G, Pieber TR, Amrein K (2013) Vitamin $\mathrm{D}$ and immune function. Nutrients, 5, 2502-2521

6. Kim JI, Kang MJ (2012) Recent consumption and physiological status of vitamin D in Korean population. Food Ind Nutr, 17, 7-10

7. Bischoff-Ferrari HA, Giovannucci E, Willett WC, Dietrich T, Dawson-Hughes B (2006) Estimation of optimal serum concentrations of 25-hydroxyvitamin D for multiple health outcomes. Am J Clin Nutr, 84, 18-28

8. Lips P (2001) Vitamin D deficiency and secondary hyperparathyroidism in the elderly: consequences for bone loss and fractures and therapeutic implications. Endocr Rev, 22, 477-501

9. Bouillon R, Bischoff-Ferrari H, Willett W (2008) Vitamin $\mathrm{D}$ and health: perspectives from mice and man. $\mathrm{J}$ Bone Miner Res, 23, 974-979

10. Li YC, Kong J, Wei M, Chen ZF, Liu SQ, Cao LP (2002) 1,25-Dihydroxyvitamin $D_{(3)}$ is a negative endocrine regulator of the renin-angiotensin system. J Clin Invest, $110,229-238$

11. Andress DL (2006) Vitamin D in chronic kidney disease: a systemic role for selective vitamin $\mathrm{D}$ receptor activation. Kidney Int, 69, 33-43

12. Ginde AA, Liu MC, Camargo CA Jr (2009) Demographic differences and trends of vitamin $\mathrm{D}$ insufficiency in the US population, 1988-2004. Arch Intern Med, 169, 626-632

13. Thuesen B, Husemoen L, Fenger M, Jakobsen J, Schwarz P, Toft U, Ovesen L, Jorgensen T, Linneberg A (2012) Determinants of vitamin D status in a general population of Danish adults. Bone, 50, 605-610

14. Cinar N, Harmanci A, Yildiz BO, Bayraktar M (2014) Vitamin D status and seasonal changes in plasma concentrations of 25-hydroxy vitamin D in office workers 
in Ankara, Turkey. Eur J Intern Med, 25, 197-201

15. Yu AR, Kim JH, Kwon OR, Oh SY, Kim JH, Yang YJ (2014) Associations between serum 25-hydroxy vitamin $\mathrm{D}$ and consumption frequencies of vitamin $\mathrm{D}$ rich foods in Korean adults and older adults. Korean $\mathbf{J}$ Community Nutr, 19, 122-132

16. Lim SK, Kung AWC, Sompongse S, Soontrapa S, Tsai KS (2008) Vitamin D inadequacy in postmenopausal women in Eastern Asia. Curr Med Res Opin, 24, 99-106

17. Ji SH, Jang MY, Choi JY, Choi YM, Kim YG (2015) A study on contents of vitamin D in agricultural products and foods. Korean J Food Nutr, 28, 143-152

18. MFDS (2014) Ministry of Food and Drug Safety. Food Code I, Cheongju, Korea, p 104-107

19. Son BY, Kim JT, Song SY, Baek SB, Kim CK, Kim JD (2009) Comparison of yield and forage quality of silage corns at different planting dates. J Kor Grassl Forage Sci, 29, 179-186

20. Kuhn J, Schroter A, Hartmann BM, Stangl GI (2018) Cocoa and chocolate are sources of vitamin D2. Food Chem, 269, 318-320

21. Cardwell G, Bornman JF, James AP, Black LJ (2018) A review of mushrooms as a potential source of dietary vitamin D. Nutr, 10, 1498-1509
22. Choi SJ (2017) Enhancement of ergocalciferol (vitamin D) content in mushrooms by UV irradiation. Korean $\mathbf{J}$ Food Preserv, 24, 381-386

23. Lee JS, Kim SJ, Ahn RM, Choi HS, Choi HR, Yoon SK, Hong WS, Hang HS, Kwon DJ, Kim YJ (2002) The effect of UV-B irradiation and hot-air drying on the vitamin D2 content of shiitake mushroom (Lentinus edodes). Korean J Food Cookery Sci, 18, 173-178

24. Krzyczkowski W, Malinowska E, Suchocki P, Kleps J, Olejnik M, Herold F (2009) Isolation and quantitative determination of ergosterol peroxide in various edible mushroom species. Food Chem, 113, 351-355

25. Yokoyama S, Banga TH, Shimizua K, Kondo R (2012) Osteoclastogenesis inhibitory effect of ergosterol peroxide isolated from Pleurotus eryngii. Nat prod commun, 7, 1163-1164

26. Schmid A, Walther B (2013) Natural vitamin D content in animal products. Adv Nutr, 4, 453-462

27. Browning LC, Cowieson AJ (2014) Vitamin D fortification of eggs for human health. J Sci Food Agric, 94, 1389-1396

28. Kim EM, Lim JH, Chang YJ, An SH, An MY (2015) Changes in the quality characteristics of cricket (Gryllus bimaculatus) under various processing conditions. Korean J Food Preserv, 22, 218-224 